\title{
Ultrastructural study of regressed and reactivated testes from Soay rams
}

\author{
D. Mortimer* and G. A. Lincoln
}

Department of Obstetrics \& Gynaecology, and M.R.C. Reproductive Biology Unit, University of Edinburgh, Centre for Reproductive Biology, 37 Chalmers Street, Edinburgh EH3 9EW, U.K.

\begin{abstract}
Summary. Testes from 4 sexually active and 4 sexually regressed adult Soay rams housed under artificial lighting were examined. The reduction in testis weight during sexual regression (reduced to $35 \%$ of active) was due to a decrease in the diameter of the seminiferous tubules with extensive involution of the basement membrane, a marked reduction in the number of germ cells maturing beyond the spermatocyte stages, and a general disorganization of all but the most basal region of the seminiferous epithelium. The Sertoli cells contained large lipid droplets and deposits of lipochrome pigment and large necrotic bodies. The Leydig cells showed some reduction in content of smooth endoplasmic reticulum during sexual regression although they were approximately 30 times less active steroidogenically as judged by the peripheral levels of testosterone. Blood levels of LH and FSH were significantly reduced compared to those in sexually active animals, while the prolactin levels were much increased.
\end{abstract}

\section{Introduction}

Seasonal changes in the spermatogenic and androgenic activity of the testes occur in a wide range of mammals (see reviews by Lodge \& Salisbury, 1970; Lincoln, 1981). In many animals, regression of the testes in the non-mating season involves complete arrest of spermatogenesis and a marked reduction in the secretion of testosterone, leading to infertility of the male. The histological changes that occur in the seminiferous tubules and interstitium in relation to seasonal regression have been described at the light microscope level for many species, but there have been few studies illustrating the changes in ultrastructure. Ultrastructural observations have been made of the active and regressed testes of the mole, Talpa europaea (Aumuller \& Schafer, 1972), hyrax, Procavia capensis (Neaves, 1973), grey squirrel, Sciurus carolinensis (Pudney \& Lacy, 1977), and Australian native rat, Rattus fuscipes (Kerr, Keogh, Hudson, Whipp \& de Kretser, 1980).

The purpose of the present study was to record the seasonal changes in the fine structure of the testes of the adult Soay ram, a primitive unimproved breed of sheep which shows a pronounced cycle in testicular activity. The animals used in the study were housed under an artificial lighting regimen to control the timing of the seasonal effects; details of the endocrine changes in these rams have been published elsewhere (Lincoln \& Short, 1980).

* Present address: Department of Obstetrics \& Gynaecology, University of Birmingham, Birmingham Maternity Hospital, Edgbaston, Birmingham B 15 2TG, U.K. 


\section{Materials and Methods}

Morphology. Testes from 8 mature, 7-9-year-old Soay rams were used. The animals were housed under an artificial lighting regimen of alternating 16-week periods of long days (16 h light:8 h darkness; 16L:8D) and short days (8L:16D) for 4 years which induced cycles of regression and re-development of the testes every 32 weeks. Throughout the whole period lights were switched on at 08:00 h. Four rams (Group R) were castrated when the testes were regressed (after 12 weeks' exposure to long days), and another 4 (Group A) when the testes were fully enlarged (after 12 weeks' exposure to short days). Excised testes and epididymides were weighed.

After excision of the testes the testicular artery was cannulated, the testis was perfused with $0.9 \%(\mathrm{w} / \mathrm{v}) \mathrm{NaCl}$ to wash all blood from the vascular network, and then fixed by perfusion with Karnovsky's (1965) cacodylate-buffered formaldehyde-glutaraldehyde at $60 \%(\mathrm{v} / \mathrm{v})$ strength for $30 \mathrm{~min}$. Small blocks of tissue were cut from each testis and fixation was completed by immersion for $3 \mathrm{~h}$ in fresh fixative. This material was rinsed 3 times in buffer and pieces not exceeding $1.5 \mathrm{~mm}$ in any direction were post-fixed for $1 \mathrm{~h} \mathrm{in} 1 \%(\mathrm{w} / \mathrm{v})$ osmium tetroxide and rinsed in 3 more changes of buffer. Dehydration was accomplished by a graded series of acetones, and propylene oxide was used as the transitional solvent. After impregnation through a series of $2: 1,1: 2$ and $0: 1$ propylene oxide :araldite mixtures, the tissue was embedded in araldite which was polymerized at $60^{\circ} \mathrm{C}$ for $48 \mathrm{~h}$.

Silver sections were cut on a Reichert OmU3 ultramicrotome using glass knives and stained on 200 -mesh copper grids with $2 \%(\mathrm{w} / \mathrm{v})$ uranyl acetate in $50 \%(\mathrm{v} / \mathrm{v})$ methanol, and lead citrate (Reynolds, 1963). Grids were viewed in a Philips EM301 transmission electron microscope operating at an accelerating voltage of $60 \mathrm{kV}$, and micrographs were taken on Kodak 4463 electron image film.

Larger pieces of each testis were also taken after the initial perfusion fixation and immersed in Bouin's fluid for $24 \mathrm{~h}$ before processing for routine paraffin-wax embedding. Measurement of the seminiferous tubule diameters was made on $6 \mu \mathrm{m}$ histological sections (stained with haematoxylin and eosin) of each testis; 30 tubules were chosen at random and measured for each animal.

Endocrinology. Blood samples were collected from the jugular vein of the rams at 30-min intervals for 4-6 h immediately before castration and the plasma concentrations of luteinizing hormone $(\mathrm{LH})$, follicle-stimulating hormone $(\mathrm{FSH})$, prolactin and testosterone were measured by radioimmunoassay. Details of the assay methods have been published elsewhere (LH: Scaramuzzi, Caldwell \& Moor, 1970; FSH: McNeilly, McNeilly, Walton \& Cunningham, 1976; prolactin: McNeilly \& Andrews, 1974; testosterone: Corker \& Davidson, 1978). Statistical comparisions were made using Student's $t$ test.

\section{Morphology}

\section{Results}

The testes and epididymides of the rams in Group $\mathbf{R}$ were significantly reduced in size and weight compared to these organs from Group A rams (see Table 1). The reduction in size of the testes was associated with a decrease in the diameter of the seminiferous tubules with a concomitant infolding of the basement membrane revealing its laminar substructure (see Pl. 1, Fig. 1, Pl. 2, Fig. 2). In Group R testes the seminiferous epithelium appeared disorganized (Pl. 1, Fig. 1, Pl. 2, Fig. 2), with occasional spermatids and spermatozoa at the luminal border but with relatively few spermatocytes undergoing meiosis. All sections showed large deposits of lipid in droplets which were often up to $8 \mu \mathrm{m}$ in diameter. Large necrotic bodies (apparently residual material from degenerating spermatogenic cells) were evident within the Sertoli cells, and deposits of lipochrome pigment were also common. 
Table 1. Comparison of reproductive data (mean \pm s.e.m. of 4 animals) for adult Soay rams at the regressed and reactivated phases of the testicular cycle controlled artificially by exposure to alternating 4-month periods of long (16L:8D) and short (8L:16D) days

\begin{tabular}{lccc}
\hline & \multicolumn{2}{c}{ Stage of the testicular cycle } & \\
\cline { 2 - 3 } & $\begin{array}{c}\text { Group R, } \\
\text { regressed } \\
\text { (long days) }\end{array}$ & $\begin{array}{c}\text { Group A, } \\
\text { reactivated } \\
\text { (short days) }\end{array}$ & $\begin{array}{c}\text { Significance } \\
\text { of difference }\end{array}$ \\
\hline Testis weight* $(\mathrm{g})$ & $52.0 \pm 3.9$ & $147.6 \pm 14.1$ & $P<0.01$ \\
Testis diam. $\dagger(\mathrm{mm})$ & $43.5 \pm 1.4$ & $58.5 \pm 0.9$ & $P<0.01$ \\
Seminiferous tubule diam. $\neq(\mu \mathrm{m})$ & $155.0 \pm 1.7$ & $237.5 \pm 2.1$ & $P<0.001$ \\
Epididymis weight* $(\mathrm{g})$ & $19.4 \pm 1.2$ & $33.0 \pm 4.2$ & $P<0.05$ \\
Plasma testosterone $(\mathrm{ng} / \mathrm{ml})$ & $0.5 \pm 0.1$ & $15.1 \pm 1.3$ & $P<0.01$ \\
Plasma LH§ $(\mathrm{ng} / \mathrm{ml})$ & $0.3 \pm 0.1$ & $1.4 \pm 0.2$ & $P<0.01$ \\
Plasma FSH $\$(\mathrm{ng} / \mathrm{ml})$ & $22.0 \pm 2.0$ & $137.0 \pm 18.0$ & $P<0.01$ \\
Plasma prolactin $\$(\mathrm{ng} / \mathrm{ml})$ & $36.0 \pm 7.0$ & $1.0 \pm 0.2$ & $P<0.01$ \\
\hline
\end{tabular}

*Right side only.

†Measured externally through the scrotum before castration.

$\ddagger$ Calculated from measurements of 30 tubules from each animal.

$\S$ Based on blood samples collected at 30-min intervals for $6 \mathrm{~h}$ immediately before castration.

In the testes from Group A rams the seminiferous epithelium showed distinct organization with all the usual cellular associations of the spermatogenic cycle ( $\mathrm{Pl}$. 3, Figs 3 and 4). The tubules were expanded and the basement membrane was flat. Groups of synchronously developing spermatids were seen in some sections; these were linked by intercellular bridges and all stages of spermiogenesis were evident. Large lipid droplets were found in some sections, although they were much less abundant than in those of Group $\mathbf{R}$, as were necrotic bodies and lipochrome deposits.

The appearance of the Leydig cells of the interstitial tissue was similar in the testes of both groups (Pl. 4, Figs 5 and 6). There were subjective indications of denser staining cytoplasm, larger densely staining vesicles, and more nuclear heterochromatin in the Leydig cells from the Group $\mathbf{R}$ testes. Cytometric analysis of micrographs of Leydig cells from the two groups indicated that there was up to $75 \%$ less smooth endoplasmic reticulum (SER) volume in the Group R Leydig cells, although there were insufficient data available to perform statistical correlations between SER content and testosterone concentrations.

\section{Endocrinology}

The concentrations of $\mathrm{LH}, \mathrm{FSH}$ and testosterone in the blood plasma of the Group A rams were much increased compared to the values from animals in Group $\mathrm{R}$, while the prolactin concentrations were decreased (Table 1).

\section{Discussion}

The testes of the Soay rams in Group $\mathbf{R}$ were about one-third the weight of those from active animals in Group A. This seasonal change is more pronounced than in other breeds of domesticated sheep such as the Romney (Barrell \& Lapwood, 1979) and the Ile-de-France (Hochereau-de Reviers, Loir \& Pelletier, 1976), but not as spectacular as in some wild seasonally breeding species (Lincoln, 1981). 
The seasonal change in the size of the testes of the Soay ram was largely due to a change in the bulk of the seminiferous tubule rather than a change in the amount of interstitial tissue. During regression of the testes there was a marked shrinkage of the tubule diameter and the basement membrane was correspondingly infolded. The adluminal compartment of the seminiferous epithelium showed disorganization of the normal cell associations, and few germ celis had matured beyond the spermatocyte stage. Necrotic cells were common in the regressed testes, along with debris of disintegrating cells often located within the cytoplasm of the Sertoli cells.

\section{PLATES 1-4}

Abbreviations: $\mathrm{A}=$ type- $\mathrm{A}$ spermatogonium; $\mathrm{B}=$ type- $\mathrm{B}$ spermatogonium; $\mathrm{BM}=$ basement membrane; $\mathbf{L}=$ lipid droplet; $\mathbf{M}=$ myoid cell; $\mathbf{N}=$ nucleus; $\mathrm{n}=$ nucleolus; $\mathbf{P}=$ lipochrome pigment; $\mathrm{S}=$ Sertoli cell; $\mathrm{Sc}=$ spermatocyte; $\mathrm{Sd}=$ spermatid; $\mathrm{SN}=$ Sertoli cell nucleus; ${ }^{*}=$ collagen; arrow $=$ inter-Sertoli cell tight junction; arrowhead $=$ necrotic body.

\section{PLATE 1}

Fig. 1. Basal region of seminiferous epithelium from a regressed testis (Ram S7). The basement membrane is involuted, and can be seen to have a lamellar substructure. Two type-A spermatogonia and a Sertoli cell are attached to the basement membrane. A late spermatid is visible in an unusual position within the epithelium, and lies next to a large (mostly extracted) lipid droplet. Only in the basal region can any cell associations be recognized; in more adluminal areas there is complete disorganization of the epithelium. The interstitial tissue has myoid cells of normal appearance, and large deposits of collagen fibres showing their characteristic striated substructure. $\times 5670$.

\section{PLATE 2}

Fig. 2. Basal region of seminiferous epithelium from another regressed testis (Ram S8). In this animal the involution and lamination of the basement membrane is again pronounced. A Sertoli cell, with its characteristic nucleus, and small stretches of inter-Sertoli cell junctions can be seen. The seminiferous epithelium is totally disorganized, the only recognizable spermatogenic cell being a spermatocyte (probably pachytene) at the top of the picture. Lipid droplets, lipochrome pigment and necrotic bodies (a large example of which is shown in the inset, same magnification) are common features. $\times 5670$.

\section{PLATE 3}

Fig. 3. In this micrograph from a reactivated testis (Ram S9) an organized progression from type-B spermatogonium through primary and secondary spermatocytes is present. The basement membrane is not involuted and shows little evidence of lamination. $\times 4540$.

Fig. 4. In the testis of this reactivated animal (Ram S1) the basement membrane is again flat, with only slight evidence of lamination. Tight junctions between two Sertoli cells isolate a type-A spermatogonium in the basal compartment of the epithelium. Testicular reactivation in this tubule has left behind some large lipid droplets, one of which is visible in the micrograph (almost totally extracted), and some necrotic bodies remain within the Sertoli cells. $\times 5600$.

\section{PLATE 4}

Figs 5 and 6. Typical Leydig cells from reactivated (Fig. 5, Ram S9) and regressed (Fig. 6, Ram S6) testes. There were no significant morphological differences between the Leydig cells of the 8 animals studied, all had mitochondria with tubular cristae and extensive SER with only occasional short lengths of rough ER. In regressed testes there was up to $75 \%$ less volume of SER (cytometric point counts were $62 / 100$ for Fig. 5 and 28/100 for Fig. 6). These cells are typical in that there is an indication of darker staining cytoplasm with larger densely-staining vesicles in the Group R Leydig cell. The Leydig cell with a nucleus (there are actually parts of 3 Leydig cells in the micrograph) from the active testis (Fig. 5) appears to have less heterochromatin than the Leydig cell nucleus in Fig. 6. Both these cells show the typical 'halo' of cytoplasm free of mitochondria and SER around their nuclei (see Christensen, 1975). $\times 7690$. 


\section{PLATE 1}

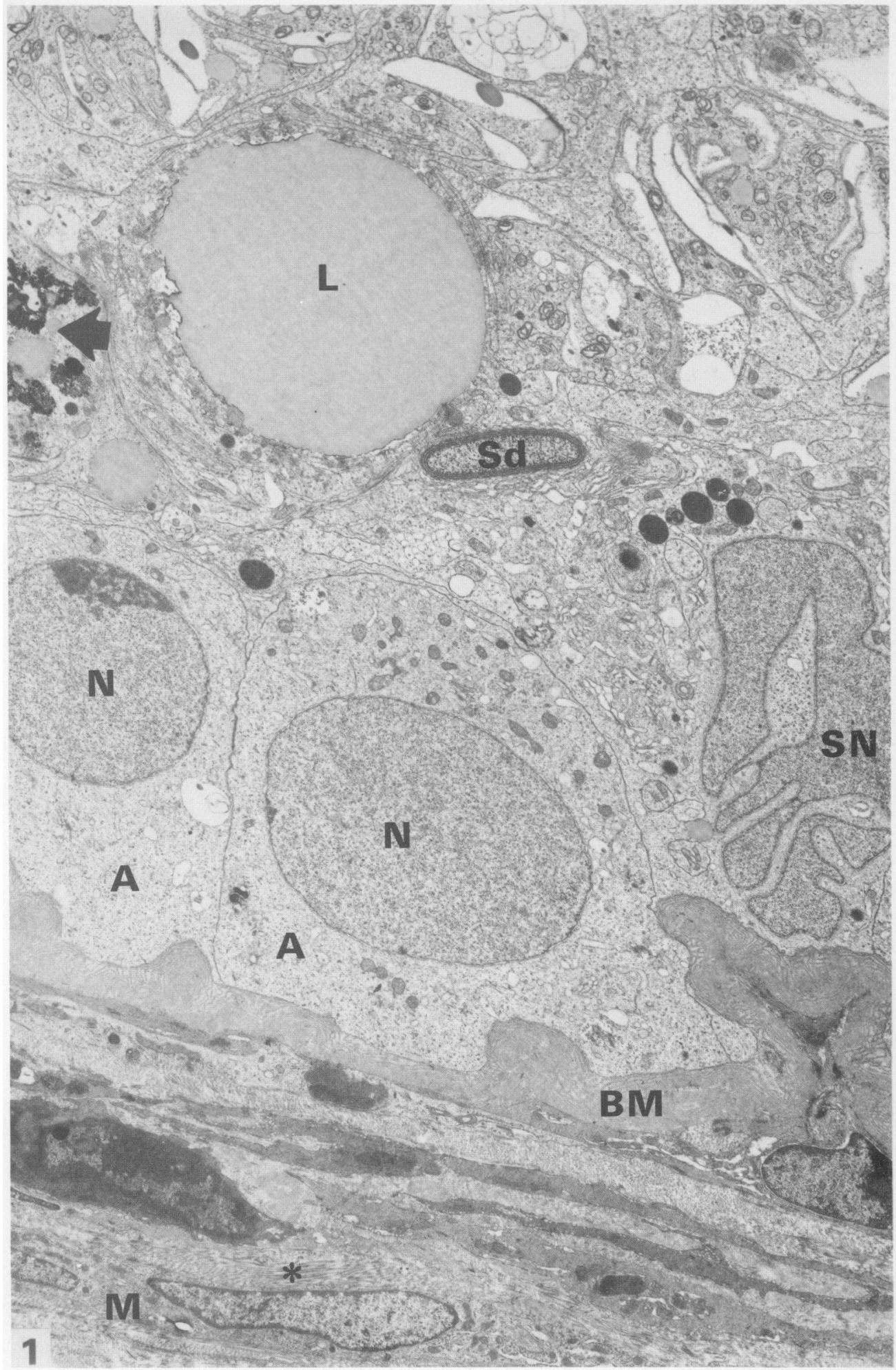

(Facing p.440) 


\section{PLATE 2}
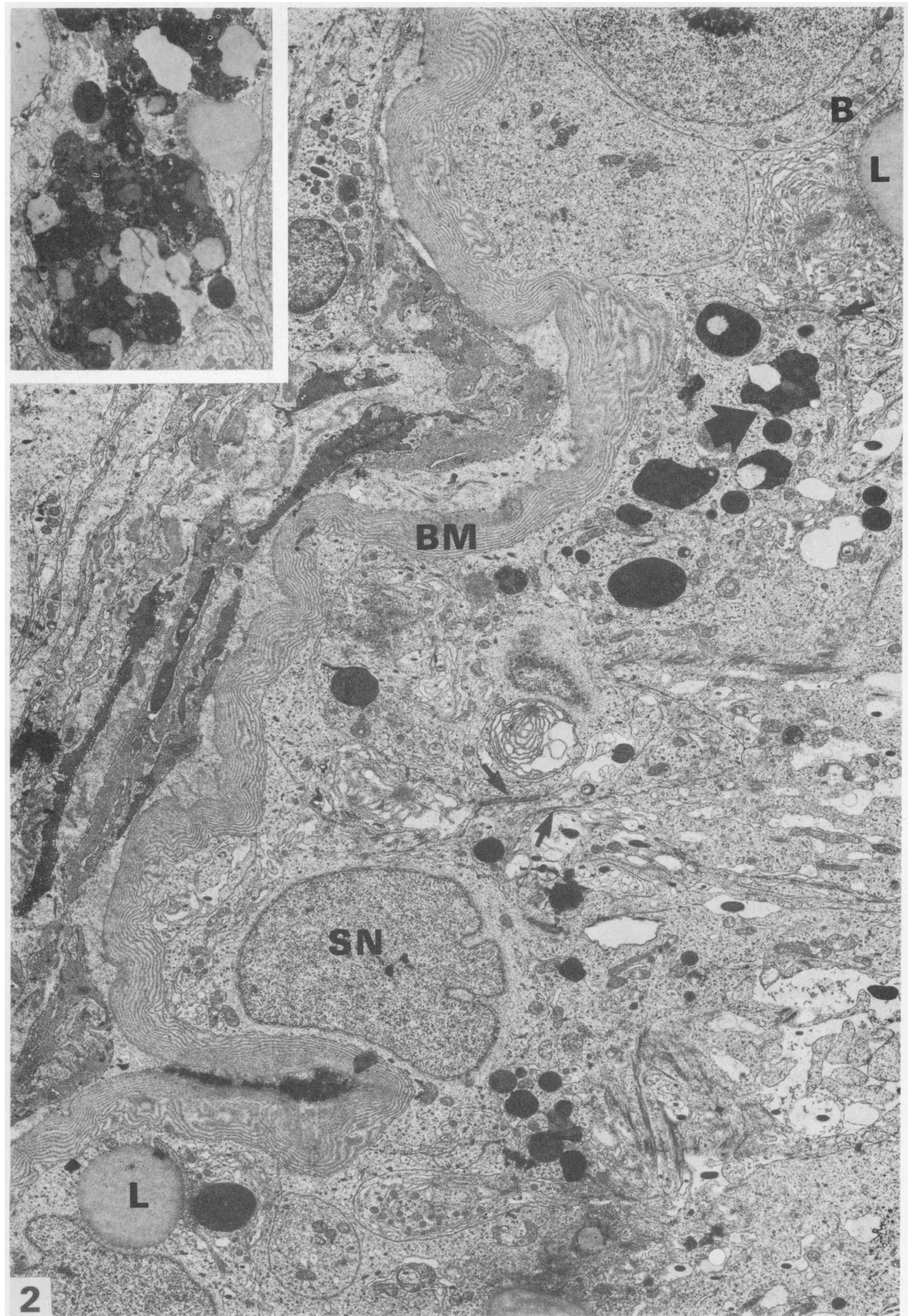
PLATE 3

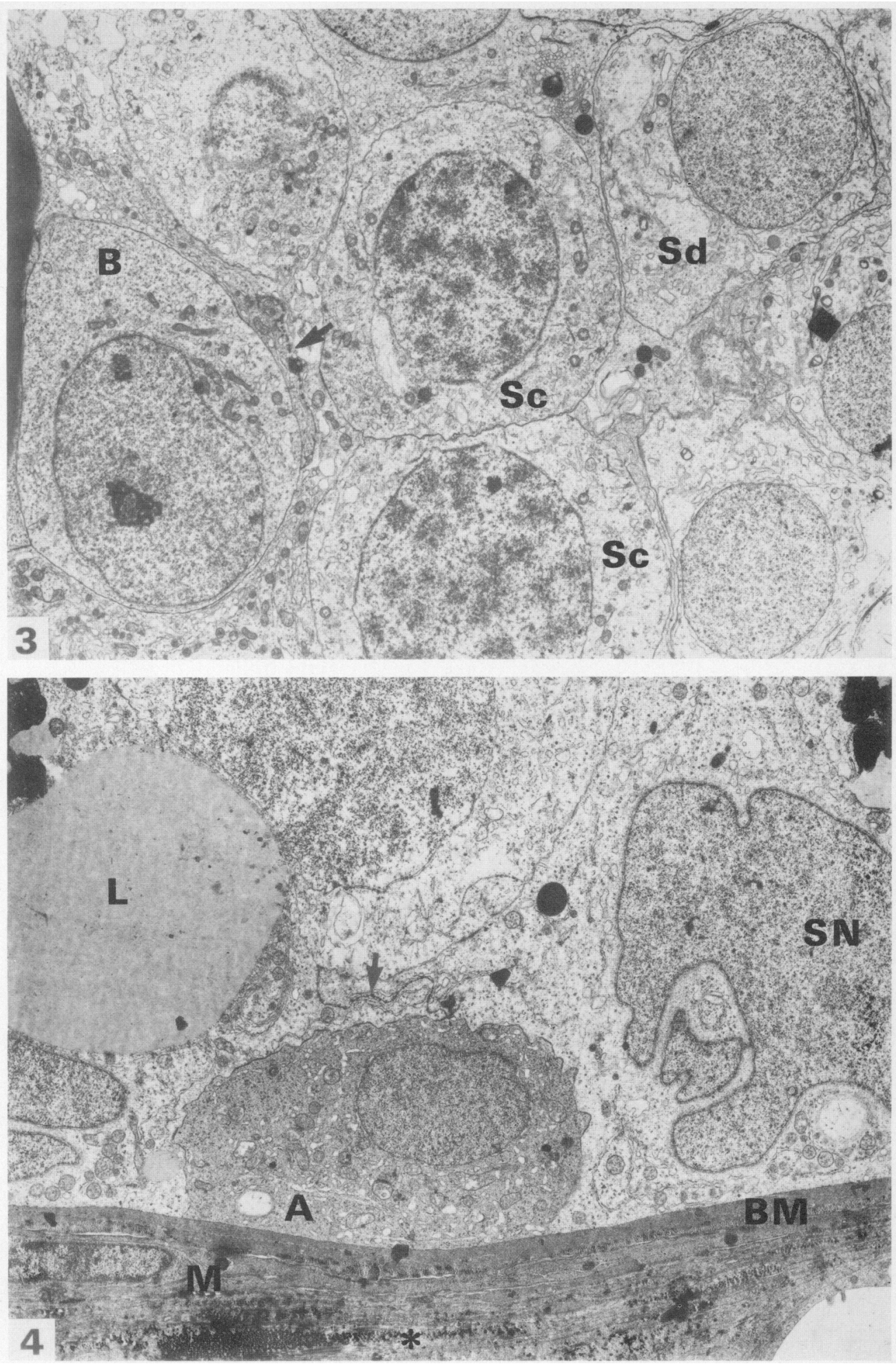


PLATE 4
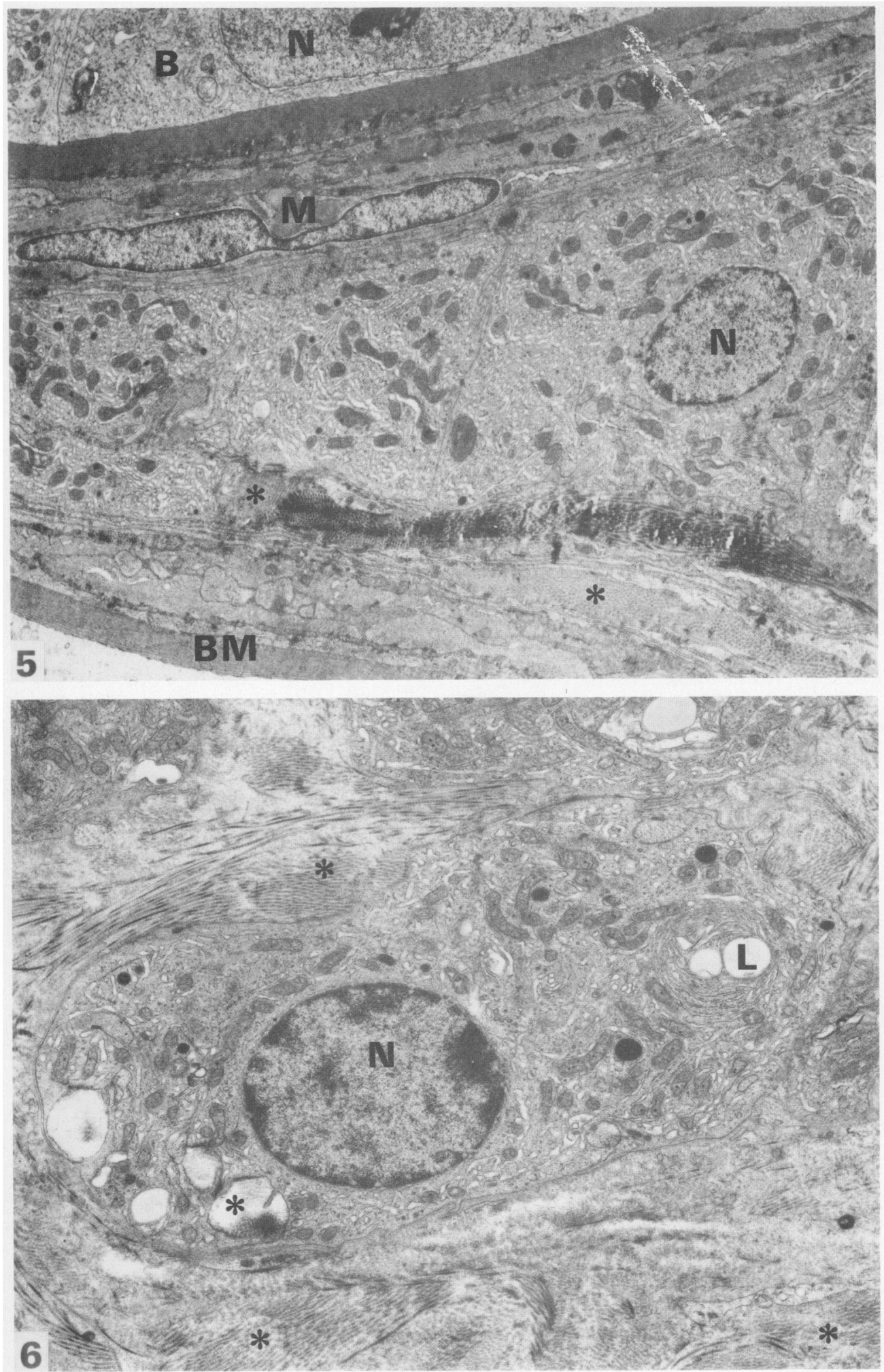
From the present material it was not possible to perform a quantitative assessment of the spermatogenic process as.hes been done for a number of other species, including the vole (Grocock \& Clarke, 1975), Île-de-France sheep (Hochereau-de Reviers et al., 1976) and red deer (Hochereau-de Reviers \& Lincoln, 1978) in which there is also a marked seasonal change in the number of matúring spermatozoa. In these species mitosis and meiosis continue during seasonal regression but cells die at various stages of spermatogenesis so that few spermatozoa are produced. Kerr et al. (1980) described an arrest of spermatogenesis at the spermatocyte stage during regression in the native Australian rat, Rattus fuscipes, as well as seasonal variation in the lipid content of the Sertoli cells with the deposition of large lipid droplets as a feature of the regressed seminiferous epithelium.

In the Soay rams the Leydig cells in the sexually active and non-breeding animals showed all the features typical of a steroidogenically active cell type (see Christensen, 1975). While the Leydig cells of the active testes were producing some 30 times more testosterone than the regressed testes, as judged by the blood steroid concentrations, there was clear evidence of a reduction in SER content in only some of the Leydig cells of Group $\mathrm{R}$ rams; there was therefore a poor correlation between form and function. Extensive deposits of collagen, recognized by the characteristic striations of its substructure, were found in the interstitial tissue of all Soay ram testes examined, and no evidence for seasonal variation in this material could be found. From studies on the homogenization of testicular tissue for estimation of the daily sperm production rates, it has been noted that ram testes are considerably more fibrous than those of the bull, boar, rabbit or man (D. Mortimer, unpublished results). Since all the Soay rams were of equivalent age (see 'Materials and Methods'), extensive collagen deposits, while possibly being age-related, are probably a feature of ram testes in general.

The seasonal changes in the activity of the testes are controlled by the pattern of secretion of gonadotrophins from the anterior pituitary gland, and in the present study the concentrations of LH and FSH in the peripheral blood were markedly reduced in the rams with regressed testes while at this time the levels of prolactin were high. The importance of the changes in $\mathrm{LH}$ and FSH is emphasized by the observation that seasonal regression of the testes can be reversed by administration of LH-RH (Lincoln, 1979) while spermatogenesis can be stimulated in hypophysectomized rams by treatment with a combination of LH and FSH (Courot, 1971). Prolactin does not appear to be important for spermatogenesis in the ram (Barenton \& Pelletier, 1980). The effect of gonadotrophins is to stimulate the functional activity of the Leydig (testosterone production) and Sertoli (including androgen-binding protein production) cells, thereby allowing the germ cells to divide and differentiate to become spermatozoa. When gonadotrophin levels are low, as in seasonal regression, the germ cells die and spermatogenesis is disrupted.

During this study D.M. was in receipt of a Wellcome Trust Interdisciplinary Linked Fellowship. We thank Dr R. Stockwell of the Department of Anatomy for access to EM facilities, and Mr F. M. Johnston for assistance with the electronmicrography.

\section{References}

Aumuller, G. \& Schafer, A. (1972) Histochemie und Feinstruktur der Zwischenzellen des Maulwurfhodens (Talpa europaea L.) wahrend der Abklingphase der Spermogenese. Acta histochem. 43, 235-253.

Barenton, B. \& Pelletier, J. (1980) Prolactin, testicular growth and $\mathrm{LH}$ receptors in the ram following light and 2-Br- $\alpha$-Ergocryptine (CB-154) treatments. Biol. Reprod. 22, 781-790.
Barrell, G.K. \& Lapwood, K.R. (1979) Effects of various lighting regimens and pinealectomy on semen production in Romney rams. J. Reprod. Fert. 57, 273-279.

Christensen, A.K. (1975) Leydig cells. In Handbook of Physiology, section 7, vol. V: Male Reproductive System, Ch. 3, pp. 57-94. Eds D. W. Hamilton \& R. O. Greep. American Physiological Society, Washington, D.C. 
Corker, C.S. \& Davidson, D.W. (1978) The radioimmunoassay of testosterone in various biological fluids without chromatography. J. Steroid Biochem., 9, 373-374.

Courot, M. (1971) Establissement de la spermatogenèse chez l'agneau (Ovis aries). Thèse de Doctorat D'Etat Es-Sciences Naturelles, Paris.

Grocock, C.A. \& Clarke, J.R. (1975) Spermatogenesis in mature and regressed testes of the vole (Microtus agrestis). J. Reprod. Fert. 43, 461-470.

Hochereau-de Reviers, M.T. \& Lincoln, G.A. (1978) Seasonal variation in testicular activity in the red deer (Cervus elaphus). J. Reprod. Fert. 54, 209-213.

Hochereau-de Reviers, M.T., Loir, M. \& Pelletier, J. (1976) Seasonal variation in the response of the testis and $\mathbf{L H}$ levels to hemicastration of adult rams. $J$. Reprod. Fert. 46, 203-209.

Karnovsky, M.J. (1965) A formaldehyde-glutaraldehyde fixative of high osmolality for use in electron microscopy. J. Cell Biol. 27, 137A, Abstr.

Kerr, J.B., Keogh, E.J., Hudson, B., Whipp, G.T. \& de Kretser, D.M. (1980) Alterations in spermatogenic activity and hormonal status in a seasonally breeding rat, Rattus fuscipes. Gen. comp. endocr. 40, 78-88.

Lincoln, G.A. (1979) Use of a pulsed perfusion of luteinizing hormone releasing hormone to mimic seasonally induced endocrine changes in the ram. $J$. Endocr. 83, 251-260.

Lincoln, G.A. (1981) Seasonal aspects of testicular function. In The Testis, pp. 255-302. Eds H. Burger \& D. de Kretser. Raven Press, New York.
Lincoln, G.A. \& Short, R.V. (1980) Seasonal breeding: Nature's contraceptive. Recent Prog. Horm. Res. 36, $1-52$.

Lodge, J.R. \& Salisbury, G.W. (1970) Seasonal variation and male reproductive efficiency. In The Testis, Vol. III, Ch. 4, pp. 139-167. Eds A. D. Johnson, W. R. Gomes \& N. L. VanDemark. Academic Press, New York.

McNeilly, A.S. \& Andrews, P. (1974) Purification and characterization of caprine prolactin. J. Endocr. 60, 359-367.

MeNeilly, J.R., McNeilly, A.S., Walton, J.S. \& Cunningham, F.J. (1976) Development and application of a heterologous radioimmunoassay for ovine follicle-stimulating hormone. J. Endocr. 70, 67-79.

Neaves, W.B. (1973) Changes in testicular Leydig cells and in plasma testosterone levels among seasonally breeding rock hyrax. Biol. Reprod. 8, 451-466.

Pudney, J. \& Lacy, D. (1977) Correlation between ultrastructure and biochemical changes in the testis of the American grey squirrel, Sciurus carolinensis, during the reproductive cycle. J. Reprod. Fert. 49, 5-16.

Reynolds, E.S. (1963) The use of lead citrate at high pH as an electron-opaque stain in electron microscopy. J. Cell Biol. 17, 208-212.

Scaramuzzi, R.J., Caldwell, B.V. \& Moor, R.M. (1970) Radioimmunoassay of $\mathrm{LH}$ and estrogen during the estrous cycle of the ewe. Biol. Reprod. 3, 110-119.

Received 20 May 1981 